\title{
USAHATANI TANAMAN TEH RAKYAT (Camellia Sinensis) \\ (Studi Kasus pada Kelompok Tani Mulus Rahayu, di Desa Mekartani, Kecamatan Singajaya, Kabupaten Garut, Provinsi Jawa Barat)
}

\author{
BUDI GINANJAR*, MUHAMMAD ARIEF BUDIMAN, LUCYANA TRIMO \\ Program Studi Agribisnis, Departemen Sosial Ekonomi Pertanian, Fakultas Pertanian, Universitas \\ Padjadjaran \\ *Email: ginanjar190@gmail.com
}

\begin{abstract}
ABSTRAK
Melemahnya kondisi agribisnis teh rakyat di Kabupaten Garut saat ini menyebabkan harga jual pucuk tanaman teh yang semakin murah dengan ditandai semakin menurunnya angka penerimaan usahatani dan rendahnya pendapatan usahatani yang diterima oleh para petani teh rakyat di Kabupaten Garut. Tujuan penelitian ini yaitu untuk mendeskripsikan keragaan usahatani yang dilaksanakan oleh para petani teh rakyat yang tergabung ke dalam kelompok tani Mulus Rahayu yang berlokasi di Kabupaten Garut. Selain itu, tujuan utama penelitian ini yaitu untuk menganalisis nilai dari usahatani teh rakyat mulai dari nilai penerimaan usahatani, biaya usahatani, dan pendapatan usahatani. Hasil penelitian menunjukkan bahwa keragaan usahatani yang dilaksanakan oleh petani teh rakyat telah sesuai dengan SOP (Standard Operational Procedure) yang dianjurkan. Kegiatan usahatani teh rakyat telah memberikan pendapatan bagi petani di lokasi penelitian berkisar antara $\mathrm{Rp} 2.902 .060$ sampai dengan Rp 16.535.000 per tahun, dengan nilai $\mathrm{R} / \mathrm{C}$ yaitu 2,72 sampai dengan 4,69 dan niilai $\mathrm{B} / \mathrm{C} \quad 1,72$ sampai 3,69.
\end{abstract}

Kata kunci: Usahatani, Keragaan, Pendapatan, Teh Rakyat

\section{ABSTRACT}

The weakening of the agribusiness condition of the residents' tea in Garut Regency currently causes the selling price of tea plant more cheaply with the marked decreasing of farm revenue and low income of farming received by the tea farmers in Garut regency. The imbalance between the selling price of the lower tea bud and the higher purchase price of fertilizer cause the condition of tea farming system in Garut regency is getting in slump condition. The purpose of this research was to describe the farming performance owned by residents' tea farmers which was incorporated to Mulus Rahayu farmers group located at Garut regency. In addition, the main purpose of this research was to analyze the value of residents' tea farming started from value of farming revenue, farming cost, and farming income. Result of study indicated that farming performance which was done by residents' tea farmers have been corresponding with the suggested SOP (Standard Operational Procedure). Activities of residents' tea farming has given income in location of research accepted ranged between $R p 2.902 .060$ up to Rp 16.535.000 per year, with value of $r / c$ was 2,72 until 4,69 and value of $b / c$ was 1,72 until 3,69.

Keywords: Farming, Performance, Income, Residents' Tea

\section{PENDAHULUAN}

Teh merupakan salah satu minuman yang sangat populer dikonsumsi di banyak negara. Teh sebagai salah satu komoditi hasil perkebunan yang mempunyai peran cukup penting dalam kegiatan perekonomian di Indonesia, yakni sebagai salah satu penghasil devisa negara sesudah minyak dan gas. Hal ini ditunjang dengan perkebunan teh di Indonesia yang cukup luas dan dengan 
jumlah produksi teh yang sangat besar (Setyamidjaja, 2001).

Teh terbuat dari pucuk daun tanaman teh (Camellia sinensis) melalui proses pengolahan tertentu. Berdasarkan cara/proses pengolahannya, teh dapat dibagi menjadi tiga jenis, yaitu teh hijau, teh oolong, dan teh hitam. Teh hitam merupakan jenis teh yang paling banyak di produksi di Indonesia, dimana Indonesia sendiri merupakan pengekspor teh hitam ke-5 terbesar di dunia. (Ghani, 2002).

Provinsi Jawa Barat merupakan provinsi dengan luas areal dan jumlah produksi teh terbesar di Indonesia dari dulu hingga sampai saat ini. Menurut sumber tahun terakhir angka tetap data statistik tahun 2015, Dinas Perkebunan Provinsi Jawa Barat, tercatat provinsi Jawa Barat memiliki total luas perkebunan teh seluas 87.608 ha dengan keseluruhan total produksi teh mencapai $90.594 \mathrm{~kg}$. semuanya terbagi ke dalam tiga penguasaan lahan yaitu Perkebunan Rakyat (PR), Perkebunan Besar Swasta (PBS), dan Perkebunan Besar Negara $(\mathrm{PBN})^{\mathbf{1}}$.

Produsen teh di provinsi Jawa Barat juga terdiri atas PTPN, swasta dan petani

1) Dinas Perkebunan Provinsi Jawa Barat, Angka Tetap Buku Statistik Tahun 2015, komoditi teh . teh rakyat. Berdasarkan luas arealnya, perkebunan teh rakyat menempati urutan pertama jika dibandingkan dengan dua jenis perkebunan lainnya. Untuk lebih jelasnya bisa dilihat pada Tabel 1 .

Tabel 1. Luas Areal Perkebunan Teh Menurut Kepemilikan di Provinsi Jawa Barat Tahun $2011-2015$

\begin{tabular}{cccc}
\hline Tahun & PR (ha) & PS (ha) & PN (ha) \\
\hline 2011 & 48.399 & 20.899 & 25.700 \\
2012 & 48.636 & 21.023 & 25.191 \\
2013 & 48.456 & 20.889 & 25.046 \\
2014 & 45.850 & 20.916 & 23.213 \\
2015 & 46.209 & 20.781 & 20.618 \\
\hline \multicolumn{4}{l}{ Sumber : Dinas Perkebunan Provinsi Jawa Barat } \\
\end{tabular}

Keterangan : PR $=$ Perkebunan Rakyat PS $=$ Perkebunan Swasta $\mathrm{PN}=$ Perkebunan Negara

Berdasarkan Tabel 1 terlihat bahwa perkebunan teh milik rakyat memiliki peranan yang cukup penting bagi perekonomian khususnya sektor pertanian di Provinsi Jawa Barat.

Besarnya luas perkebunan teh rakyat di Jawa Barat sudah pasti diiringi juga semakin banyaknya petani yang menggantungkan perekonomiannya di sektor pertanian, khususnya komoditi teh ini. Pada tahun 2015, data statistik menunjukan bahwa sebanyak 74.204 Kepala Keluarga (KK) di provinsi Jawa Barat yang memiliki areal perkebunan teh rakyat yang tersebar di berbagai daerah Provinsi Jawa Barat ${ }^{2}$.

\footnotetext{
2) Dinas Perkebunan Provinsi Jawa Barat, Angka Tetap Luas dan Produksi Tanaman Tahunan
} 
Data statistik Dinas Perkebunan Provinsi Jawa Barat pada tahun 2015, menunjukan bahwa kabupaten Garut menempati posisi kelima sebagai kabupaten dengan luas areal tanaman perkebunan teh milik rakyat di provinsi Jawa Barat yaitu dengan total luas lahan mencapai 4.309 ha. Sedangkan untuk jumlah produksi teh, kabupaten Garut menempati posisi ke empat sebagai penyumbang produksi terbesar teh rakyat di Jawa Barat yaitu dengan jumlah produksi sebesar 4.399 ton, kalah dari Kabupaten Tasikmalaya, Cianjur, dan Purwakarta ${ }^{3}$.

Kondisi teh yang sedang mengalami permasalahan di Jawa Barat juga diikuti oleh Kabupaten Garut, bahwa di Kabupaten Garut saat ini eksistensi perkebunan teh rakyat sedang mengalami ketidakstabilan, hal ini diperkuat berdasarkan hasil wawancara peneliti dengan salah satu staf Dinas Perkebunan Kabupaten Garut, khususnya bagian Perlindungan dan Pengembangan Usaha Perkebunan, yaitu Anita Hastari, beliau memaparkan:

"Saat ini harga pucuk teh di tingkat petani Kabupaten Garut sangat rendah. Sekitar Rp 1.600/kg sampai

Perkebunan Rakyat Provinsi Jawa Barat, Komoditi Teh . Tahun 2015.

3) Dinas Perkebunan Provinsi Jawa Barat, Tahun 2015 dengan harga Rp 1.900/kg. Sudah hampir tiga tahun perkebunan teh rakyat di Garut dalam kondisi tidak stabil, seperti istilahnya hidup segan mati tak mau karena di Kabupaten Garut sedang gencargencarnya penanaman dan pemeliharaan komoditas kopi, imbasnya banyak petani yang tadinya mengusahakan tanaman teh beralih lahan menjadi perkebunan kopi. Ya semoga ke depannya kondisi perkebunan teh rakyat di Garut bisa kembali positif, baik dari segi harga jual pucuk teh yang semakin tinggi, maupun dari segi semakin produktivitas teh"4. meningkatnya

Berdasarkan hasil wawancara dengan salah satu staf Dinas Perkebunan Kabupaten Garut bagian Perlindungan dan Pengembangan Usaha Perkebunan, yaitu Anita Hastari, beliau menyatakan bahwa saat ini kondisi teh khususnya teh perkebunan rakyat di Kabupaten Garut sedang dalam kondisi ketidakstabilan. Kondisi tersebut ditandai dengan semakin menurunnya angka produktivitas teh rakyat di tiap kecamatan sentra produksi teh rakyat di Kabupaten Garut.

Lemahnya kondisi teh juga dipicu karena faktor bahwa saat ini komoditas teh kalah bersaing dengan komoditas kopi yang sedang terus menerus dikembangkan

\footnotetext{
4) Hasil wawancara langsung dengan Anita Hastari sebagai bagian Perlindungan dan Pengembangan Usaha Perkebunan, Dinas Perkebunan Kabupaten Garut, pada tanggal 13 Juni 2017
} 
di Kabupaten Garut. Dan sebagaimana yang diinformasikan oleh Anita Hastari melalui wawancara langsung dengan peneliti, murahnya harga jual pucuk teh dan rendahnya pendapatan yang diterima petani menjadi faktor utama yang mengakibatkan perkembangan komoditas teh rakyat di Kabupaten Garut mengalami ketidakstabilan.

Melamahnya kondisi agribisnis teh rakyat di Kabupaten Garut juga diakui oleh ketua Kelompok Tani Mulus Rahayu yaitu Jalal Nurhadi. Beliau memaparkan saat ini para petani teh rakyat yang tergabung dalam kelompok tani Mulus Rahayu sedang mengalami permasalahan berupa murahnya harga jual pucuk teh dan rendahnya angka pendapatan yang di terima oleh para petani.

Sebagai dampak dari murahnya harga jual pucuk teh, banyak pemilik lahan teh yang beralih dari awalnya berusahatani teh lalu kemudian membudidayakan tanaman lain seperti singkong, cabai, dan tanaman keras (kayu). Selain murahnya harga jual pucuk teh di pasaran, saat ini para anggota petani Mulus Rahayu sedang dihadapkan pula dengan permasalahan perbedaan harga di tiap pembeli pucuk teh. Menurut informasi yang diperoleh peneliti dari ketua kelompok tani Mulus Rahayu, perbedaan harga dikarenakan adanya dua perusahaan yang menawarkan harga berbeda dalam membeli pucuk teh kepada para petani yang tergabung dalam Kelompok Tani Mulus Rahayu.

Maka dari itu, berdasarkan permasalahan yang saat ini dihadapi oleh Kelompok Tani Mulus Rahayu juga berdasarkan atas fakta-fakta yang ditemukan peneliti di lapangaan melalui observasi, peneliti terdorong untuk melakukan penelitian yang berkaitan langsung dengan usahatani perkebunan teh rakyat yang saat ini sedang dijalankan dan dibudidayakan oleh para petani di kelompok tani mulus rahayu

Hasil dari penelitian ini kedepannya diharapkan dapat menghasilkan suatu analisis mengenai seberapa besarkah tingkat pendapatan yang diterima oleh petani mulus rahayu dalam kegiatan usahatani teh rakyat ini. Analisis biaya dan penerimaan juga akan dikaji dalam penelitian ini yang kemudian nantinya akan menghasilkan besarnya nilai efesiensi usahatani, sehingga apakah usahatani teh rakyat yang dibudidayakan sudah berada di posisi layak serta menguntungkan atau bahkan berada pada kondisi yang tidak layak untuk diusahakan dikarenakan merugikan para petani Mulus Rahayu. Rekomendasi dalam usaha 
meningkatkan pendapatan petani teh rakyat menjadi tujuan akhir dilakukannya penelitian kali ini.

\section{METODE PENELITIAN}

Objek dalam penelitian ini adalah para petani yang tergabung ke dalam Kelompok Tani Mulus Rahayu yang melakukan kegiatan usahatani tanaman teh yang berada di Desa Mekartani, Kecamatan Singajaya, Kabupaten Garut. Penelitian ini mengkaji tentang kegiatan proses usahatani teh rakyat mulai dari pemeliharaan hingga proses penjualan pucuk teh selama kurun waktu satu tahun kegiatan produksi usahatani tanaman teh rakyat.

Penelitian ini menggunakan desain penelitian kualitatif dengan pendekatan kuantitatif. Pendekatan kuantitatif digunakan untuk mengetahui nilai usahatani tanaman teh rakyat melalui analisis biaya produksi, penerimaan, dan pendapatan usahatani. Sedangkan desain kualitatif dibutuhkan untuk menjelaskan secara mendalam mengenai identifikasi kondisi keragaan usahatani teh rakyat saat ini yang dimiliki oleh para petani Kelompok Tani Mulus Rahayu di Kecamatan Singajaya, Kabupaten Garut. Desain kualitatif menggunakan analisis deskriptif sebagai alat untuk mengolah dan menganalisis data yang didapatkan sehingga bisa menggambarkan secara jelas mengenai kondisi keragaan usahatani milik petani kelompok tani Mulus Rahayu.

Teknik penelitian yang digunakan adalah studi kasus. Studi kasus biasa dilakukan kepada individu atau sebuah kelompok untuk mengetahui suatu masalah secara mendalam (Sugiyono, 2011). Teknik studi kasus dilakukan oleh peneliti dengan survey deskriptif. Survey deskriptif akan dilakukan dengan explanatory survey dengan maksud untuk menggabungkan fenomena dan juga menjelaskan sebab-akibat terjadinya fenomena tersebut. Survey deskriptif ini sebagai tindak lanjut dari informasi data kuantitatif yang telah didapat untuk dianalisis lebih lanjut mengenai kegiatan usahatani tanaman teh.

Untuk melakukan pengumpulan data primer adalah dengan pengamatan langsung dan wawancara dengan responden sekaligus informan yang terkait dengan penelitian ini. Pada tahap ini diberikan beberapa pertanyaan yang bertujuan untuk mendapatkan faktorfaktor kunci informasi, seperti gambaran umum mengenai profil Kelompok Tani Mulus Rahayu, gambaran awal mengenai usahatani perkebunan teh rakyat, serta 
permasalahan-permasalahan yang saat ini sedang dihadapi oleh para petani Mulus Rahayu. Adapun responden sekaligus informan yang terkait dengan Kelompok Tani Mulus Rahayu adalah Jalal Nurhadi selaku Ketua Kelompok Tani dan selaku penampung hasil panen teh para petani anggota kelompok tani Mulus Rahayu.

Teknik pengumpulan data dan informasi terbagi ke dalam tiga cara, yaitu wawancara, observasi, serta studi kepustakaan. Data primer didapatkan dari hasil wawancara langsung dengan informan kunci dan informan pendukung serta didapatkan dari hasil observasi langsung di lapangan, sedangkan data sekunder di dapatkan dari hasil telaah studi kepustakaan baik dari jurnal ilmiah maupun yang berasal dari internet seperti angka statistika perkebunan teh rakyat.

Sedangkan untuk metode pengolahan dan analisis data di dalam penelitian ini yaitu menggunakan alat analisis berupa analisis deskriptif untuk menggambarkan kondisi keragaan usahatani teh rakyat, analisis usatani untuk melihat nilai dari usahatani teh rakyat, serta analisis efisiensi dan kelayakan usahatani teh rakyat untuk menganalisis sejauh mana usahatani teh rakyat dapat memberikan keuntungan bagi para petani di lokasi penelitian
HASIL DAN PEMBAHASAN Keragaan Usahatani Teh Rakyat

Keragaan usahatani menunjukkan bagaimana suatu usahatani dapat berhasil dijalankan, atau dengan kata lain keragaan usahatani menjelaskan bagaimana faktorfaktor produksi atau input suatu unit yang dapat mempengaruhi keberhasilan suatu usahatani. Keragaan usahatani dapat berbeda untuk beberapa daerah dalam mengusahakan satu produk komoditas yang sama. Indikator yang dapat mempengaruhi keragaan usahatani bersumber dari dua faktor, yaitu faktor intern dan faktor ekstern. Faktor intern berkaitan dengan petani secara langsung, seperti karakteristik petani itu sendiri yaitu usia, pendidikan, pengalaman usahatani, luas lahan, tanggungan keluarga, dan modal petani. Sedangkan faktor ekstern merupakan indikator yang berasal dari luar petani itu sendiri, seperti penggunaan bibit tanaman teh, pupuk, penggunaan tenaga kerja, hasil panen, dan pemasaran pucuk teh.

Dilihat dari indikator ekstern, beberapa faktor yang harus diperhatikan dalam budidaya serta kegiatan usahatani tanaman teh antara lain: pengadaan dan penggunaan input produksi pertanian, teknik budidaya tanaman teh, serta faktor kegiatan panen dan pasca panen. 
Sarana produksi yang dimaksud dalam budidaya tanaman teh meliputi lahan, bibit, pupuk dan pestisida, tenaga kerja, alat-alat pertanian dan modal. Pada teknik budidaya tanaman teh hal yang paling penting untuk diperhatikan adalah pembersihan lahan/penyiangan, pemupukan, pemakaian herbisida untuk rumput liar, pengendalian hama penyakit tanaman, serta pemangkasan pada tanaman teh. Kegiatan panen pada tanaman teh dapat meliputi rumus petik yang digunakan oleh petani pada saat pemetikan pucuk teh, cara pemetikan pucuk teh, serta frekuensi pemetikan dalam satu bulan pada saat musim kemarau dan musim penghujan. Sedangkan kegiatan pascapanen meliputi penanganan pucuk di lapangan dan proses penjualan pucuk teh kepada pembeli. Pengetahuan petani terhadap aspek pemasaran pucuk teh penting untuk dikuasai sebagai upaya untuk mengoptimalkan pendapatan usahatani dari hasil budidaya tanaman teh bagi para petani di lokasi penelitian.

\section{Analisis Usahatani Tanaman Teh Rakyat (Camellia Sinensis)}

Analisis usahatani merupakan alat analisis yang digunakan untuk melihat seberapa besarkah nilai dari kegiatan usahatani dapat memberikan keuntungan bagi para petani yang melakukan kegiatan usahatani suatu komoditas tertentu. Dalam melakukan analisis usahatani tidak akan terlepas dari beberapa faktor yang sangat menentukan bagi suatu keberhasilan usahatani, yaitu faktor penerimaan usahatani, biaya usahatani, serta pendapatan dari usahatani itu sendiri. Analisis efisiensi dan kelayakan usahatani juga turut dimasukkan untuk melihat sejauh manakah usahatani tersebut berada pada kondisi layak dan menguntungkan atau malah sebaliknya.

\section{Penerimaan Usahatani}

Penerimaan usahatani dalam budidaya tanaman teh merupakan nilai produksi yang diperoleh dalam jangka waktu tertentu dan merupakan hasil antara jumlah produksi total pucuk teh yang dihasilkan dalam kurun waktu satu tahun dikali dengan harga rata-rata pucuk teh yang berlaku selama tahun 2017. Total produksi pucuk teh yang dihasilkan oleh para petani informan kelompok tani Mulus Rahayu selama tahun 2017 mencapai sebanyak 94.608 kilogram pucuk teh. Petani informan yang memiliki nilai produksi pucuk teh paling rendah selama tahun 2017 yaitu hanya mampu menghasilkan produksi pucuk tanaman teh sebanyak 2.564 kilogram pucuk 
dengan luas lahan 0,5 hektar. Sedangkan petani informan yang memiliki produksi pucuk tanaman teh terbesar selama tahun 2017 mampu menghasilkan sebanyak 12.200 kilogram pucuk teh dengan luas lahan kebun teh seluas 2,2 hektar. Harga yang berlaku untuk tiap satu kilogram pucuk teh selama tahun 2017 telah mengalami lima kali perubahan harga, yaitu harga jual pucuk teh terendah sebesar $\mathrm{Rp} 1.700 / \mathrm{Kg}$ dan untuk harga tertinggi pucuk teh adalah sebesar $\mathrm{Rp}$ $2.000 / \mathrm{Kg}$.

Tabel 2. Penerimaan Usahatani Tanaman Teh Rakyat Para Petani Informan Kelompok Tani Mulus Rahayu Selama Tahun 2017

\begin{tabular}{cccr}
\hline Informan & $\begin{array}{c}\text { Luas } \\
\text { Lahan } \\
(\mathrm{Ha})\end{array}$ & $\begin{array}{c}\text { Total } \\
\text { Produksi } \\
(\mathrm{Kg})\end{array}$ & $\begin{array}{c}\text { Total } \\
\text { Penerimaan } \\
(\mathrm{Rp})\end{array}$ \\
\hline 1 & 1 & 6.314 & 11.302 .060 \\
2 & 0,8 & 4.354 & 7.793 .660 \\
3 & 1,5 & 8.212 & 14.699 .480 \\
4 & 1,2 & 5.928 & 10.611 .120 \\
5 & 0,8 & 4.300 & 7.697 .000 \\
6 & 1 & 5.340 & 9.558 .600 \\
7 & 0,5 & 2.670 & 4.779 .300 \\
8 & 1 & 5.520 & 9.880 .800 \\
9 & 1,1 & 5.860 & 10.489 .400 \\
10 & 0,7 & 3.870 & 6.927 .300 \\
11 & 0,5 & 2.564 & 4.589 .560 \\
12 & 1,7 & 10.134 & 18.139 .860 \\
13 & 2 & 11.800 & 21.122 .000 \\
14 & 2,2 & 12.200 & 21.838 .000 \\
15 & 1,3 & 5.540 & 9.916 .600 \\
\hline
\end{tabular}

Tabel 2 menunjukan bahwa besarnya nilai penerimaan usahatani yang diperoleh para petani informan pada kelompok tani Mulus Rahayu dari kegiatan budidaya usahatani tanaman teh rakyat yang paling tinggi adalah sebesar
$\mathrm{Rp} 21.838 .000$ dengan total produksi pucuk teh pada tahun 2017 mencapai 12,2 ton dalam luasan lahan kebun teh seluas 2,2 hektar. Sedangkan petani informan yang paling rendah mendapatkan penerimaan usahatani pada tahun 2017 yaitu hanya sebesar Rp 4.589.560 dengan luas lahan kebun teh hanya sebesar 0,5 hektar dan total produksi pucuk teh yang dihasilkan selama tahun 2017 hanya mencapai tota produksi sebanyak 2,5 ton. Hal tersebut tentu sangat tidak sebanding dengan luas perkebunan teh yang dimiliki oleh petani teh tersebut.

\section{Biaya Usahatani}

Biaya usahatani didefinisikan sebagai nilai semua masukan yang habis terpakai di dalam produksi. Menurut Soehardjo dan Patong (1977), biaya usahatani dapat berbentuk biaya tunai dan biaya diperhitungkan. Biaya tunai adalah biaya yang dibayar dengan uang, seperti pembelian sarana produksi dan biaya upah tenaga kerja. Biaya yang diperhitungkan digunakan untuk menghitung berapa pendapatan kerja petani yang sesungguhnya jika pajak lahan, biaya penyusutan alat, dan upah tenaga kerja dalam keluarga diperhitungkan dan dimasukkan ke dalam biaya usahatani. Upah tenaga kerja keluarga dinilai 
berdasarkan upah yang berlaku di lokasi penelitian.

Untuk kasus usahatani tanaman teh rakyat di lokasi penelitian, petani mengeluarkan biaya tunai dalam melakukan kegiatan usahatani tanama teh rakyat. Petani melakukan pembelian terhadap sarana produksi pertanian seperti pupuk (Urea, KCL, dan TSP), herbisida, dan membayar tenaga kerja yang berasal dari luar keluarga tetapi tidak mengeluarkan biaya sewa lahan karena petani menggarap lahan milik pribadi tanpa dibebani dengan biaya sewa lahan pertahunnya. Sedangkan yang termasuk ke dalam biaya yang diperhitungkan dalam kegiatan usahatani tanaman teh rakyat milik kelompok tani Mulus Rahayu adalah biaya tenaga kerja dalam keluarga dan biaya penyusutan alat pertanian.

Tabel 3. Biaya Total Usahatani Tanaman Teh Rakyat Per Tahun Masing-masing Petani Informan

\begin{tabular}{cccc}
\hline Informan & $\begin{array}{c}\text { Luas } \\
\text { Lahan } \\
(\mathrm{Ha})\end{array}$ & $\begin{array}{c}\text { Total } \\
\text { Produksi } \\
(\mathrm{Kg})\end{array}$ & $\begin{array}{c}\text { Biaya Total } \\
\text { Usahatani } \\
(\mathrm{Rp})\end{array}$ \\
\hline 1 & 1 & 6.314 & 3.131 .000 \\
2 & 0,8 & 4.354 & 2.028 .500 \\
3 & 1,5 & 8.212 & 3.770 .000 \\
4 & 1,2 & 5.928 & 3.243 .000 \\
5 & 0,8 & 4.300 & 2.001 .000 \\
6 & 1 & 5.340 & 2.490 .500 \\
7 & 0,5 & 2.670 & 1.643 .000 \\
8 & 1 & 5.520 & 2.615 .000 \\
9 & 1,1 & 5.860 & 2.650 .000 \\
10 & 0,7 & 3.870 & 1.775 .500 \\
11 & 0,5 & 2.564 & 1.687 .500 \\
12 & 1,7 & 10.134 & 3.871 .500 \\
13 & 2 & 11.800 & 4.931 .000 \\
14 & 2,2 & 12.200 & 5.303 .000 \\
15 & 1,3 & 5.540 & 3.121 .000 \\
\hline
\end{tabular}

Berdasarkan Tabel 3 dapat diketahui bahwa total biaya usahatani yang dikeluarkan oleh tiap masing-masing petani informan untuk kegiatan usahatani tanaman teh rakyat selama periode waktu satu tahun memiliki besar total biaya usahatani yang bervariatif mulai dari biaya yang terendah adalah sebesar $\mathrm{Rp}$ 1.643.300 dan yang terbesar yaitu dengan total pengeluaran biaya usahatani sebesar Rp 5.303.000.

Ketersediaan lahan garapan yang memiliki kesamaan luas antar sesama petani informan tidak sama sekali akan mempengaruhi dalam jumlah pengeluaran biaya total usahatani yang juga memiliki kesamaan dalam biaya yang akan dikeluarkan, contohnya saja petani informan dengan nomor 1,6 , dan 8 meskipun memiliki luas lahan perkebunan teh seluas satu hektar, jumlah total biaya usahatani antar ketiga petani informan tersebut memiliki besar pengeluaran berbeda-beda, dimana hal yang akan mempengaruhi ke dalam jumlah biaya total usahatani yang akan dikeluarkan tersebut antara lain dari proses pembelian pupuk, jumlah sewa tenaga kerja selama satu tahun, dan besarnya biaya penyusutan peralatan yang harus dikeluarkan setiap tahunnya oleh petani informan tersebut. 


\section{Pendapatan Usahatani}

Pendapatan usahatani merupakan balas jasa dari kerja sama faktor-faktor produksi lahan, tenaga kerja, modal, dan pengelolaan. Analisis pendapatan usahatani dilakukan untuk menentukan pendapatan yang diperoleh dari suatu usahatani tanaman teh rakyat dalam periode waktu kegiatan selama satu tahun.

Pendapatan usahatani tanaman teh rakyat merupakan selisih dari penerimaan dengan biaya yang dikeluarkan, dengan demikian dapat dilihat sejauh manakah peranan usahatani tanaman teh rakyat yang sedang dilaksanakan oleh seluruh petani informan yang terkait terhadap pendapatan keluarga tani di daerah penelitian. Analisis ini terdiri atas struktur biaya dan penerimaan usahatani teh rakyat. Selain itu, dengan analisis ini dapat diketahui gambaran usahatani yang sedang dilaksanakan oleh seluruh petani informan sehingga dapat melakukan evaluasi untuk perencanaan kegiatan usahatani pada masa yang akan datang,

Pendapatan total usahatani tanaman teh rakyat dapat dianalisis berdasarkan jumlah luas lahan yang dimiliki oleh setiap petani informan. Lahan perkebunan teh rakyat dengan jumlah luas yang dimiliki oleh setiap petani informan tidak akan menjamin dalam semakin besarnya pendapatan total usahatani teh rakyat yang akan diperoleh, bisa saja terjadi kepada petani yang memiliki lahan kebun teh luas namun memperoleh pendapatan total usahatani yang rendah, sedangkan petani yang memiliki luas lahan kebun teh yang rendah malah justru memperoleh pendapatan total usahatani yang lebih tinggi dari petani informan yang memiliki lahan kebun teh yang lebih luas.

Hal ini bisa saja dipengaruhi oleh beberapa faktor seperti populasi pohon teh lebih banyak, proses pemupukan tanaman teh yang lebih teratur, perlakuan dan perawatan kebun teh lebih diperhatikan dan dijaga sehingga akan berdampak kepada produktivitas kebun teh yang lebih tinggi walaupun jumlah luasan lahan kebun teh yang dimiliki lebih rendah.

Tabel 4. Pendapatan Total Usahatani Teh Rakyat Para Petani Informan Selama Satu Tahun

\begin{tabular}{crrr}
\hline No & $\begin{array}{c}\text { Total } \\
\text { Penerimaan } \\
(\mathrm{Rp})\end{array}$ & $\begin{array}{c}\text { Biaya } \\
\text { Total } \\
\text { Usahatani } \\
(\mathrm{Rp})\end{array}$ & $\begin{array}{c}\text { Pendapatan } \\
\text { Usahatani } \\
(\mathrm{Rp})\end{array}$ \\
\hline 1 & 11.302 .060 & 3.131 .000 & 8.171 .060 \\
2 & 7.793 .660 & 2.028 .500 & 5.765 .160 \\
3 & 14.699 .480 & 3.770 .000 & 10.929 .480 \\
4 & 10.611 .120 & 3.243 .000 & 7.368 .120 \\
5 & 7.697 .000 & 2.001 .000 & 5.696 .000 \\
6 & 9.558 .600 & 2.490 .500 & 7.068 .100 \\
7 & 4.779 .300 & 1.643 .000 & 3.136 .300 \\
8 & 9.880 .800 & 2.615 .000 & 7.265 .800 \\
9 & 10.489 .400 & 2.650 .000 & 7.839 .400 \\
10 & 6.927 .300 & 1.775 .500 & 5.151 .800 \\
11 & 4.589 .560 & 1.687 .500 & 2.902 .060 \\
12 & 18.139 .860 & 3.871 .500 & 14.268 .360 \\
13 & 21.122 .000 & 4.931 .000 & 16.191 .000 \\
14 & 21.838 .000 & 5.303 .000 & 16.535 .000 \\
15 & 9.916 .600 & 3.121 .000 & 6.795 .600 \\
\hline
\end{tabular}


Pada Tabel 4 sebelumnya dapat dilihat bahwa petani informan yang memperoleh pendapatan total usahatani yang paling besar adalah petani informan dengan kepemilikan lahan perkebunan teh rakyat seluas 2,2 hektar. Nilai penerimaan total usahatani yang didapatkan mencapai sebesar Rp 21.838.000 dengan biaya total yang sudah dikeluarkan dalam waktu satu tahun sebesar Rp 5.303.000. Selisih antara nilai penerimaan total usahatani teh rakyat dengan biaya total usahatani yang sudah dikeluarkan menghasilkan pendapatan total/bersih usahatani teh rakyat yaitu sebesar $\mathrm{Rp}$ 16.535.000 per tahun, atau dengan rata-rata pendapatan bersih yang diterima petani informan tersebut sebesar Rp 1.377.916 per bulan.

Sedangkan petani informan yang memperoleh pendapatan usahatani paling rendah diantara petani informan lain adalah petani informan nomor sebelas dengan kepemilikan kebun teh hanya seluas 0,5 hektar. Penerimaan usahatani sebesar Rp 4.589.560/tahun dengan biaya total usahatani yang dikeluarkan yaitu sebesar Rp 1.687.500/tahun. Besarnya nilai pendapatan total usahatani yang diterima per tahun sebesar Rp 2.902.060 atau dengan rata-rata pendapatan bersih usahatani per bulan sebesar hanya $\mathrm{Rp}$ 241.838 .

\section{Analisis Efisiensi Usahatani (R/C)}

Analisis R/C merupakan alat analisis untuk menggambarkan kondisi suatu usahatani dengan memperhitungkan setiap penerimaan yang didapatkan dengan biaya-biaya usahatani yang sudah dikeluarkan oleh setiap petani informan. Analisis $\mathrm{R} / \mathrm{C}$ terbagi ke dalam $\mathrm{R} / \mathrm{C}$ atas biaya tunai dan $\mathrm{R} / \mathrm{C}$ atas biaya total. Analisis R/C atas biaya tunai merupakan analisis efisiensi usahatani yang melihat dari segi penerimaan total usahatani dengan biaya tunai usahatani yang sudah dikeluarkan selama satu tahun. Sedangkan $\mathrm{R} / \mathrm{C}$ atas biaya total merupakan nilai efisiensi usahatani tanaman teh rakyat yang memperhitungkan total penerimaan usahatani dengan total biaya usahatani yang sudah dikeluarkan selama satu tahun.

Tabel 5. Nilai R/C Usahatani Teh Rakyat Para Petani Informan

\begin{tabular}{cccc}
\hline No & $\begin{array}{c}\text { Total } \\
\text { Penerimaan } \\
(\mathrm{Rp})\end{array}$ & $\begin{array}{c}\text { Biaya } \\
\text { Total } \\
\text { Usahatani } \\
(\mathrm{Rp})\end{array}$ & $\begin{array}{c}\mathrm{R} / \mathrm{C} \\
\text { Usahatani }\end{array}$ \\
\hline 1 & 11.302 .060 & 3.131 .000 & 3.61 \\
2 & 7.793 .660 & 2.028 .500 & 3.84 \\
3 & 14.699 .480 & 3.770 .000 & 3.90 \\
4 & 10.611 .120 & 3.243 .000 & 3.27 \\
5 & 7.697 .000 & 2.001 .000 & 3.85 \\
6 & 9.558 .600 & 2.490 .500 & 3.84 \\
7 & 4.779 .300 & 1.643 .000 & 2.91 \\
8 & 9.880 .800 & 2.615 .000 & 3.78 \\
9 & 10.489 .400 & 2.650 .000 & 3.96 \\
10 & 6.927 .300 & 1.775 .500 & 3.90 \\
11 & 4.589 .560 & 1.687 .500 & 2.72 \\
12 & 18.139 .860 & 3.871 .500 & 4.69 \\
13 & 21.122 .000 & 4.931 .000 & 4.28 \\
14 & 21.838 .000 & 5.303 .000 & 4.12 \\
15 & 9.916 .600 & 3.121 .000 & 3.18 \\
\hline
\end{tabular}


Berdasarkan Tabel 5 mengenai nilai $\mathrm{R} / \mathrm{C}$ usahatani teh rakyat yang didapatkan oleh para petani informan, dapat disimpulkan bahwa semua petani informan yang berada di lokasi penelitian dalam mengusahakan tanaman teh rakyat telah mengalami keuntungan karena nilai $\mathrm{R} / \mathrm{C}$ diatas angka 1.

Hal ini tentu menjadikan usahatani teh rakyat yang dilaksanakan oleh para petani informan masih dapat memberikan keuntungan dan kontribusi bagi pendapatan rumah tangga petani di lokasi penelitian. Nilai R/C atas biaya tunai akan lebih besar daripada nilai $\mathrm{R} / \mathrm{C}$ atas biaya total dikarenakan biaya tunai yang dikeluarkan petani lebih kecil daripada total keseluruhan biaya usahatani yang dikeluarkan.

Tanaman teh rakyat yang saat ini sedang dibudidayakan oleh seluruh petani informan yang tergabung ke dalam kelompok tani Mulus Rahayu masih bisa berkontribusi bagi pendapatan keluarga petani di lokasi penelitian dengan ditunjukkannya fakta bahwa semua usahatani teh rakyat yang dilaksanakan oleh petani tersebut memiliki nilai $\mathrm{R} / \mathrm{C}$ diatas angka 1, dimana hal tersebut menggambarkan usahatani teh rakyat berada pada kondisi yang menguntungkan dan layak untuk terus dikembangkan agar memberikan kontribusi pendapatan yang lebih untuk kedepannya.

\section{Analisis Kelayakan Usahatani (B/C)}

Analisis B/C merupakan analisis yang sedikit berbeda dari analisis $\mathrm{R} / \mathrm{C}$ sebelumnya dimana pada analisis ini yang dimasukan bukanlah dari segi penerimaan usahatani melainkan dari segi pendapatan total yang diterima oleh para petani informan dibagi dengan biaya total usahatani yang sudah dikeluarkan oleh para petani dalam mengusahakan tanaman teh. Namun secara tujuan analisis ini masih sama dengan analisis $\mathrm{R} / \mathrm{C}$ yaitu untuk melihat seberapa besarkah keuntungan yang diterima oleh para petani informan atas setiap biaya total usahatani yang sudah dikeluarkan sehingga dapat dilihat sejauh manakah peranan usahatani teh rakyat tersebut.

Berdasarkan besarnya pendapatan total usahatani yang diperoleh dan biaya total usahatani tanaman teh yang sudah dikeluarkan oleh petani, maka nilai $\mathrm{B} / \mathrm{C}$ usahatani teh rakyat dapat dilihat pada Tabel 6. 
Tabel 6. Nilai B/C Usahatani Teh Rakyat Para Petani Informan

\begin{tabular}{cccc} 
No & $\begin{array}{c}\text { Total } \\
\text { Pendapatan } \\
\text { Usahatani } \\
(\mathrm{Rp})\end{array}$ & $\begin{array}{c}\text { Biaya } \\
\text { Total } \\
\text { Usahatani } \\
(\mathrm{Rp})\end{array}$ & $\begin{array}{c}\mathrm{B} / \mathrm{C} \\
\text { Usahatani }\end{array}$ \\
\hline 1 & 8.171 .060 & 3.131 .000 & 2.61 \\
2 & 5.765 .160 & 2.028 .500 & 2.84 \\
3 & 10.929 .480 & 3.770 .000 & 2.90 \\
4 & 7.368 .120 & 3.243 .000 & 2.27 \\
5 & 5.696 .000 & 2.001 .000 & 2.85 \\
6 & 7.068 .100 & 2.490 .500 & 2.84 \\
7 & 3.136 .300 & 1.643 .000 & 1.91 \\
8 & 7.265 .800 & 2.615 .000 & 2.78 \\
9 & 7.839 .400 & 2.650 .000 & 2.96 \\
10 & 5.151 .800 & 1.775 .500 & 2.90 \\
11 & 2.902 .060 & 1.687 .500 & 1.72 \\
12 & 14.268 .360 & 3.871 .500 & 3.69 \\
13 & 16.191 .000 & 4.931 .000 & 3.28 \\
14 & 16.535 .000 & 5.303 .000 & 3.12 \\
15 & 6.795 .600 & 3.121 .000 & 2.18 \\
\hline
\end{tabular}

Diharapkan para petani agar lebih mampu melihat setiap peluang dan potensi pada lahan perkebunan teh rakyat yang dimilikinya yang mungkin masih bisa dimaksimalkan secara terus menerus baik dari segi intensifikasi tanaman teh maupun pemanfaatan lahan kebun teh untuk diusahakan dan ditanami dengan berbagai komoditi non teh agar bisa memberikan pemasukan lebih bagi pendapatan usahatani.

\section{KESIMPULAN DAN SARAN}

\section{Kesimpulan}

Berdasarkan nilai $\mathrm{B} / \mathrm{C}$ yang didapatkan oleh para petani informan dalam membudidayakan serta mengusahakan tanaman teh di lokasi penelitian menunjukkan bahwa usahatani teh rakyat berada pada kondisi yang layak untuk tetap diusahakan dengan semua petani informan memiliki nilai $\mathrm{B} / \mathrm{C}$ di atas Rp 1, itu artinya bahwa usahatani teh tersebut masih memberikan keuntungan pendapatan bagi para pelaku usaha teh rakyat yang tergabung ke dalam kelompok tani Mulus Rahayu.

Keragaan usahatani tanaman teh rakyat yang saat ini sudah dan masih dilaksanakan oleh para petani teh pada kelompok tani Mulus Rahayu di lokasi penelitian telah hampir seluruhnya menjalankan setiap kegiatan yang berhubungan dengan usahatani teh rakyat sesuai dengan SOP (Standard Operational Procedure) yang dianjurkan, keragaan usahatani teh rakyat tersebut meliputi tiga aspek penting mulai dari pengadaan dan penggunaan input sarana produksi usahatani, teknik budidaya usahatani, serta kegiatan panen dan pasca panen.

Pendapatan total usahatani teh rakyat yang diperoleh para petani informan selama periode satu tahun yaitu sebesar Rp 2.902.060 - Rp 16.535.000 dengan total keseluruhan pendapatan bersih yang diterima oleh para petani informan dalam mengusahakan tanaman teh rakyat selama tahun 2017 mencapai Rp 125.083.240. Rendahnya pendapatan total usahatani yang diperoleh dari hasil kegiatan usahatani teh rakyat selama satu 
tahun disebabkan oleh beberapa faktor diantaranya ketersediaan luas lahan kebun teh yang kecil, keterbatasan modal usahatani dan faktor pengaruh musim pada setiap produksi pucuk teh yang rendah dan mengakibatkan terjadinya penerimaan usahatani yang semakin kecil.

Nilai R/C petani informan berkisar antara 2,72 sampai dengan nilai 4,69. Itu artinya untuk seluruh petani informan yang telah melakukan kegiatan usahatani teh rakyat selama periode waktu satu tahun telah mendapatkan penerimaan sebesar Rp 2,72 sampai dengan yang paling tinggi yaitu sebesar Rp 4,69 untuk biaya total usahatani yang sudah dikeluarkan sebesar Rp 1 per tahun.

\section{Saran}

Saran yang bisa turut dimasukkan ke dalam penelitian ini yaitu mengupayakan penetrasi pasar untuk memperluas peluang mendapatkan harga jual pucuk teh yang semakin tinggi serta dibutuhkan penguatan kelembagaan khususnya peran kelompok tani dalam menekan biaya usahatani dengan cara saling membantu kegiatan usahatani antar sesama anggota mulai dari kegiatan pemeliharaan, pemupukan sampai dengan kepada kegiatan pemanenan pucuk teh agar memberikan peluang bagi setiap petani teh dalam meningkatkan pendapatan usahatani yang semakin tinggi.

\section{DAFTAR PUSTAKA}

Ali Akbar Hutzi. 2007. Analisis Pendapatan Usahatani Dan Saluran Pemasaran Teh Perkebunan Rakyat (Studi Kasus Perkebunan Teh Rakyat, Kecamatan Sukanagara, Kabupaten Cianjur, Provinsi Jawa Barat). Skripsi. Jurusan Ilmu Sosial Ekonomi Pertanian. Fakultas Pertanian. Bogor : Institut Pertanian Bogor.

Apollonaris Ratu Daton. 2008. Analisis Pendapatan Usahatani Jambu Mente (Kasus di Desa Ratulodong, Kecamatan Tanjung Bunga,Kabupaten Flores Timur, Propinsi Nusa Tenggara Timur). Skripsi. Program Sarjana Ekstensi Agribisnis. Fakultas Pertanian. Bogor : Institut Pertanian Bogor.

Ferry Herdiman. 2010. Analisis Pendapatan Usahatani Ubi Jalar Di Desa Gunung Malang Kecamatan Tenjolaya Kabupaten Bogor. Skripsi. Program Studi Agribisnis. Fakultas Pertanian. Bogor : Institut Pertanian Bogor.

Gilda Vanessa Tiku. 2008. Analisis Pendapatan Usahatani Padi Sawah Menurut Sistem Mina Padi Dan Sistem Non Mina Padi (Kasus Desa Tapos I dan DesaTapos II, Kecamatan Tenjolaya, Kabupaten Bogor, Jawa Barat). Skripsi. Program Studi Manajemen Agribisnis. Fakultas Pertanian. Bogor : Institut Pertanian Bogor.

Ika Sartika Saragih. 2007. Analisis Pendapatan Usahatani dan Pemasaran Kopi Arabika dan Kopi Robusta (Studi Kasus di Desa Tambun Raya, Kabupaten 
Simalungun, Provinsi Sumatera Utara). Program Ekstensi Manajemen Agribisnis. Fakultas Pertanian. Bogor : Institut Pertanian Bogor.

Krisnamurthi. 2001. Agribisnis Pengembangan Sinar Tani. Bahan Kuliah. Jurusan Ilmu-Ilmu Sosial Ekonomi Pertanian. Fakultas Pertanian. Bogor: Institut Pertanian Bogor.

Prastiwi. 1999. Analisis Produksi Teh dan Penentuan Saat Optimum Pemangkasan Tanaman Teh. Skripsi. Jurusan Ilrnu-llrnu Sosial Ekonorni Pertanian. Fakultas Pertanian. Bogor : lnstitut Pertanian Bogor.
Slamet Margono. 2000. Memantapkan Posisi dan Meningkatkan Peran Penyuluhan Pembangunan dalam Pembangunan. Dalam Proseding Seminar IPB Bogor : Pemberdayaan Sumber Daya Manusia Menuju Terwujudnya Masyarakat Madani. Pustaka Wira Usaha Muda.

Soekartawi. 2002. Analisis Usaha Tani. UI-Press. Jakarta

Sugiyono. 2011. Metode Penelitian Kuantitatif, Kualitatif, dan $R \& N$. Alfabeta. Bandung 